\title{
THE RELATIONSHIP BETWEEN THE USE OF A PERFORMANCE MEASUREMENT SYSTEM, ORGANIZATIONAL FACTORS, ACCOUNTABILITY, AND THE PERFORMANCE OF PUBLIC SECTOR ORGANIZATIONS
}

\author{
Muhammad Ahyaruddin \\ Faculty of Economics and Business \\ Universitas Muhammadiyah Riau \\ (ahyaruddin.muhammad@gmail.com) \\ Rusdi Akbar \\ Faculty of Economics and Business \\ Universitas Gadjah Mada \\ (rusdi.akbar@ugm.ac.id)
}

\begin{abstract}
This research studies the accountability and performance of public sector organizations. It provides empirical evidence about the relationship between the use of a performance measurement system and the organizational factors of accountability and organizational performance. We investigate the three roles of a performance measurement system (its operational use, incentive use, and exploratory use), and three organizational factors (contractibility, the legislative mandate, and management commitment). A mixed method approach with squential explanatory design was used to answer the research question. The hyphoteses testing used Structural Equation Modelling-Partial Least Square (SEM-PLS). Our findings were based on survey data from 137 SKPD officers in the local government of Yogyakarta Province, and showed that management commitment had a positive association with accountability and organizational performance. We also found a positive association between the legislative mandate and accountability. However, this research did not find any significant association among the three roles of the performance measurement system with accountability and organizational performance. Based on the institutional theory, our findings show substantial contributions by the institutional isomorphism, which was used in an appropriate manner to explain the context of public sector organizations, especially in the local government of Yogyakarta Province.
\end{abstract}

Keywords: the use of performance measurement system, organizational factors, accountability, mixed method.

\section{INTRODUCTION}

New Public Management (NPM) was introduced in Europe in the 1980s and has been widely adopted by public sector organizations, especially government agencies. The concept of NPM became an alternative method for the management of public sector organizations that were considered to be unsuccessful. The large public demand for transparancy and accountability prompted a new paradigm in the management of organizations that led to the adoption of the NPM concepts. In the spirit of reform implemention, the NPM's concepts became a major change for achieving the objectives of public sector organizations. Christensen and Laegreid (2014) revealed that reform in implementing NPM aimed to: (1) improve the efficiency of the public sector, (2) enhance the responsiveness of public agencies to their clients and customers, and (3) improve accountability.

One of the key elements that should be considered in the implementation of NPM is a performance measurement system. Performance 
measurement is one of the keys to success for public sector organizations to achieve their objectives. Several studies have shown that, through the appropriate measurement and management of performance, organizations will obtain various benefits, such as: (1) the motivation of the employees at all levels of the organization, (2) the creation of a performance improvement culture, (3) the formulation, implementation, and review of organizational strategy, and (4) an overall improved performance by the organization (Micheli and Mari, 2014). Nevertheless, NPM practices that emphasize the role of a performance measurement system in target setting, performance evaluation, and incentives provision are still problematic (Spekle and Verbeeten, 2014). There are two reasons that cause these problems to occur. The first is that NPM's exclusive focus on the role of performance measurement systems in accountability and incentive provision is too narrow. Some literature suggests that performance measurement systems can serve various different purposes and can be applied in a variety of different ways. By ignoring these other roles, NPM disregards the performance consequences of alternative ways of using a performance measurement system (Spekle and Verbeeten, 2014).

The second is that NPM focuses on the role of performance measurement systems in incentive-oriented work, and this can only be done, and work well, in conditions of high contractibility, i.e. when: (1) the goals of the organization are clear and unambiguous, (2) performance can be measured in ways that are consistent with organizational goal achievement, and (3) organizational actors know and control the transformation processes and are able to predict the likely outcomes of various alternative courses of action. If these three conditions cannot be met cumulatively, performance measures will only provide a partial representation of the main objectives of the organization, so that a strong emphasis on result targets is likely to have dysfunctional consequences. That is because the incentives induce the organizational actors to focus on target achievement rather than on organizational goals (Speke and Verbeeten, 2014).

In general, this study wanted to test empirically and provide quantitative and qualitative evidence of the relationship between the use of performance measurement systems and the organizational factors on the accountability and performance of public sector organizations. This is an important topic for study, in the current context, especially for government agencies. The trend for government agencies now is for them to report good performances and minimize excessive information about the failure of a programme. Performance reports submitted in the form of Government Institutions Performance Accountability Reports (LAKIP) have been biased (Nurkhamid, 2008). This bias arose because the performances delivered did not match the realities in practice, so that it could mislead the public, as the users of information, and ultimately result in excessive expectations of the government agencies.

This research specifically focuses on three roles of performance measurement systems (operational, incentives, and exploratory) and three organizational factors (contractibility, management commitment, and legislative mandate). This research also investigates whether the institutional isomorphism occurs in the implementation of the performance measurement systems and accountability in the public sector organizations. This research is based on the institutional theory, as one of the theories that are appropriate to explain that the changes in public sector organizations are heavily influenced by the external environment to simply gain legitimacy and political support (Ashworth et al., 2009).

This study uses the SEM-PLS approach to analyze and test the research model. The results of the study were found by conducting surveys and interviews with officials from government agencies (SKPD), which found evidence that management commitment was positively associated with accountability and organizational performance. The study also found a positive relationship between the legislative mandate and accountability. Management com- 
mitment is a form of normative isomorphism which is necessary for organizations. While the legislative mandate is a form of coercive isomorphism which is considered to be one aspect of the successful implementation of reforms in the public sector organizations. However, this research has not been able to provide empirical support for the relationship of the three roles for the use of a performance measurement system that was predicted to have an impact on the organizational performance. Likewise, the relationship between contractibility and accountability has no significant support with organizational performance.

The results of this study contribute to the public sector management accounting literature and provide a strong indication that the institutional theory is appropriate for use in explaining the context of public sector organizations. This study also contributes to the public sector organizations, especially the government agencies in the local government of Yogyakarta, to implement the appropriate performance measurement systems in order to achieve efficiency and effectiveness in their organizations. Finally, this study provides recommendations to the government to improve its accountability and public services in order to realize a faster and improved social welfare programme.

Overall this paper is organized as follows: the first section of this paper describes the problem and the context of the overall study which were discussed in the introduction. Then the next section discusses the literature review and hypotheses development, the research methods, and the results of the study and discussion. The final section of this paper presents the conclusions, implications, the limitations of the study and suggestions for further research.

\section{LITERATURE REVIEW AND HYPOTHESIS DEVELOPMENT}

\section{Institutional theory}

The institutional theory is a sociological theory that seeks to explain the structure of organizations (Scott, 1995). This theory describes a structure in which an organization adopts something in accordance with the code of ethics and culture that leads to legitimacy and support from external organizations. DiMaggio and Powell (1983) suggested that along with time, in an area that is well-established, organizations tend to move toward homogenization, although at first they show a fairly large diversity. An appropriate term to describe the process of homogenization is isomorphism.

DiMaggio and Powell (1983) distinguished two types of isomorphism: the competitive isomorphism and the institutional isomorphism. The competitive isomorphism relates to the efficiency (technical or economic explanations) and chooses a way that is cheaper, better, or more efficient for doing things. While the institutional isomorphism develops according to three mechanisms: the coercive, mimetic, and normative (DiMaggio and Powell, 1983). The coercive isomorphism comes from political influence and legitimacy problems. The pressure comes from formal or informal pressures from other organizations. While the mimetic isomorphism arises as a result of a process in response to the uncertainty of an environment in the area where the organization operates. When there is uncertainty, organizations tend to imitate other parties in order to achieve legitimacy. Finally, the normative isomorphism is usually associated with professionalism and ways of formal and informal collaboration that can lead to the homogenization of organizations (Akbar et al., 2012).

Several studies adopted the isomorphism theory, and assumed that the organization did not only compete for resources and customers, but also for political power and institutional legitimacy (Akbar et al., 2012). The institutional theory suggests that the organizations, in pursuit of legitimacy, adjust the isomorphic pressures that exist in the environment (Ashworth et al., 2009). Therefore this theory is very relevant by explaining the use of performance measurement systems as one of the NPM's concepts that is expected to provide benefits from the improved 
efficiency, accountability and service quality of public sector organizations.

\section{Accountability}

Accountability has been described as one of the golden concepts that no one can be against (Iyoha and Oyerinde, 2010). Bovens (2007) argued that accountability is increasingly being used in political discourse and policy documents because it conveys an image of transparency and trustworthiness. Roberts and Scapens (1985) as cited by Sinclair (1995) said that accountability required a relationship in which a person was asked to explain and take responsibility for their actions. However, Sinclair (1995) said that the definition of accountability depends on the ideologies, motifs, and language of our times. Sinclair (1995) suggests that accountability has dicipline specific meanings and can be defined from various perspectives. For example, an auditor discusses accountability as if it is a financial or numerical matter, a political scientists views accountability as a political imperative and legal scholars as a constitutional arrangement, while philosophers views accountability as a subset of ethics (Iyoha and Oyerinde 2010 ). The definition proposed by Sinclair (1995) which related to accountability, included five forms of accountability, namely: political accountability, public accountability, managerial accountability, professional accountability, and personal accountability.

Many researchers define accountability in accordance with the context and conditions of each. In the context of public sector organizations, Inaga (1991) as cited by Iyoha and Oyerinde (2010) said that accountability requires governments to give a reason related to the source and utilization of the public resources. Accountability in this context is related to the supervision and control of the government's behavior, preventing the development of concentrations of power, and enhancing the learning capacity and effectiveness of the public administration (Iyoha and Oyerinde, 2010). In the system of constitutional government, there are two types of accountability: (1) internal accountability, which is a type of direct accoun- tability that applies to a particular organizational system and involves direct reporting by subordinates to the superiors who hold power, and (2) external accountability, which is an indirect type of accountability that involves reporting to bodies outside the organization (Matek, 1977 as cited by Akbar, 2011).

\section{The Use of Performance Measurement Systems}

A performance measurement system is one of the key elements in the practice of the implementation of NPM. Several studies addressing the different roles of these systems have relied on several classifications to define and operationalize the use of performance measurement systems. Spekle and Verbeeten (2014) classified the use of performance measurement systems into three: (1) the operational use which is related to operational planning and monitoring processes; (2) incentives use which is related to target setting, incentives provision, and rewards; and (3) exploratory use which is related to prioritization, strategy management and learning, and policy development.

Spekle and Verbeeten (2014) revealed that in the context of its operational use, a performance measurement system is intended to measure the outputs and outcomes of organizations. The operational use involves operational planning (including the use of performance metrics for the preparation of performance), budget allocation, process monitoring, and the provision of information. Some studies suggest that this role is commonly used within an organization as a basic requirement (Hansen and Van der Stede, 2004; Spekle and Verbeeten, 2014). Hansen and Van der Stede (2004) in their research found that operational planning, performance evaluation, and strategy formulation have positive impacts on the performance of organizational units.

Furthermore, in relation to incentives, a performance measurement system has a major presence in the language of the NPM, in trying to apply the principles and practices of private sector management to the public sector (Newberry and Pallot, 2004). To promote 
efficiency, effectiveness, and accountability in the public sector, NPM encourages the idea of a performance contract mechanism in which measurable and clear performance targets should be able to guide the efforts of public officials towards the achievement of the organizational objectives. In this view, performance measurement systems are supposed to create incentives that help to align individual goals with the organizational objectives, provide valuable feedback information on the progress in achieving these objectives, and form a basis for internal and external accountability (Cavalluzzo and Ittner, 2004; Spekle and Verbeeten, 2014).

Hansen and Mowen (2007) revealed that incentive provision is closely related to performance. The objectives are to create appropriate goals, so that the manager can show the best performance of the company or organization. Similar was also expressed by Ichniowski et al. (1997) who suggested that high performance depends essentially on a program of incentives in association with job support, which includes an assessment of the work, uniform information, and job security. The incentive is one of more powerful motivations for employees to improve the quality of their performance.

The last of the performance measurement system's roles is its exploratory use. An exploratory use is conceptually associated with interactive use, and corresponds to strategy formulation and the communication of goals, strategy management and learning, and the strategic decision making role (Spekle and Verbeeten, 2014). Results from the research conducted by Spekle and Verbeeten (2014) suggest that the use of performance measurement systems for exploratory purposes can affect organizational performance. This is because the exploratory use of performance measurement systems can communicate strategy, and the communication will eliminate ambiguity and confusion about the organization's objectives. Thus, the organization will get fit and focused in pursuit of its mission and then can intrinsically motivate its public sector managers and employees (Spekle and Verbeeten, 2014).
Therefore, based on these explanations, the hypotheses can be formulated as follows:

H1: The use of performance measurement systems for operational purposes is positively associated with performance.

$\mathrm{H} 2$ : The use of performance measurement systems for incentive purposes is positively associated with performance.

H3: The use of performance measurement systems for exploratory purposes is positively associated with performance.

\section{Contractibility and Performance}

Hofstede (1981) extended the contingency framework to public sector organizations and suggested that result controls would be very useful when an organization's objectives were unambiguous, outputs were measurable, activities carried out repeatedly, and the effect of management interventions could be known. Spekle and Verbeeten (2014) used the term "contractibility" as an indicator of the degree in which the three following conditions can be met simultaneously: (1) there is a clear objective and an unambiguous organization, (2) performance can be measured in a way that is consistent with the achievement organization's ultimate objectives, and (3) organizational actors know and control the transformation process and are able to predict the likely outcomes of alternative courses of action.

Results of the research conducted by Spekle and Verbeeten (2014) found that contractibility has a direct influence on performance. Some literature also shows that clarity and the measurable objectives of organizations can contribute to performance. In public sector organizations, low contractibility will cause their employees or actors to be unable to determine satisfactory performance attributes. This happens because systematic influence managers to the outcomes is restricted or unknown (Spekle and Verbeeten, 2014). Therefore, based on the explanations, a hyphotesis can be formulated as follows:

H4: Contractibility is positively associated with performance 


\section{Management commitment}

Management commitment is one of the important factors in the use and implementation of performance measurement systems by public sector organizations. Management commitment is an emotional attachment, and a form of loyalty, by people who are members of the organization, and who devote their attention, ideas, and responsibilities in order to achieve the missions, values, and goals of their organization (Primarisanti, 2013). The implementation of a performance measurement system will be successful if there is support and commitment from all the elements that exist within the organization, starting from the top level, and working down through the middle and lower levels. There are two important characteristics of management or organizational commitment, which are a strong belief in, and acceptance of, the values and goals of the organization, and a willingness to exert all of one's efforts on behalf of the organization (Porter et al., 1974; Angle and Perry, 1981 in Sholihin and Pike, 2009).

Several empirical studies reveal that management commitment can lead to improved performance and accountability. Sholihin and Pike (2009) in their research found results that showed organizational commitment is positively associated with performance. Cavalluzzo and Ittner (2004) suggested that management commitment had a positive effect on the development of performance indicators, performance accountability and the use of performance information generated by the implementation of performance measurement systems. Meanwhile, research was conducted by Akbar et al. (2012) suggesting that management commitment had a positive effect on internal and external accountability. So also with the results of the study by Primarisanti (2013), who found that management commitment had a positive effect on performance accountability. Therefore, based on the outcomes of such research, hyphoteses can be formulated as follows:

H5: Management commitment is positively associated with performance
H6: Management commitment is positively associated with accountability

\section{Legislative mandate}

The institutional theory indicates that a legislative mandate (or regulatory requirements) is a relevant factor for organizations to successfully implement reforms in government organizations (Brignall and Modell, 2000). Akbar et al. (2012) in their research also found that a legislative mandate was positively associated with internal and external accountability. In the context of the public sector organizations in Indonesia, the existing legislative mandate is associated with the regulations and legislation. Each government organization should comply with the rules and laws made by the government, so in this case, the rules or regulations are forcing an organization to implement them.

Based on this, it can be said that the concept of isomorphism, particularly the coercive mechanisms as revealed by DiMaggio and Powell (1983) may occur in the practices of public sector organizations in Indonesia. Moreover, this was confirmed by Talbot's (2008) study on public sector organizations in the UK which revealed that public managers assess the law as one of the main drivers of change. So in this case, a legislative mandate is considered to be an important aspect for the success of any innovations which relate to the performance measurement's practice and accountability. Therefore, a hyphotesis can be proposed as follows:

H7: A legislative mandate is positively associated with accountability

\section{Accountability and Performance}

Various studies on NPM initiatives were based on the assumption that enhanced accountability would improve performance (Chistensen and Laegreid, 2014). Accountability is a complex and multi-faceted notion, so the possible influence of accountability on performance has been problematic and inconclusive, not least because performance is complex, multifaceted, and difficult to measure (Demirag and Khadaroo, 2011; Hyndman and Eden, 2001). 
Nevertheless, accountability in the NPM concept is often perceived as a tool for enhancing a government's ability to deliver the public goods and services, that is, its ability to demonstrate performance more efficiently and effectively (Dubnick, 2005; Demirag and Khadaroo, 2011).

Schillemans (2011) argued that enhancing the horizontal accountability of an executive agency may improve the organizational learning but not the democratic controls. Pollitt (2008) critically examined the proposition that a performance management system would increase the accountability of agencies, to the people and the political representation. His research used two case studies, the National Health Service in the United Kingdom and the World Governance Indicators of the World Bank. His research concluded that performance measurement cannot increase political accountability. But some researchers reject the assumption that accountability should have positive and negative effects. While Dubnick (2005) argued that the idea that accountability increased performance has been accepted without careful scrutiny, and he claimed that there was an "accountability paradox" in which accountability actually diminished organizational performance. Meanwhile, Yowi (2011) found that the development of performance measurement systems directly affects performance accountability and the use of performance information. Her research also found an indirect effect between the development of performance measurement systems and the use of performance information through performance accountability. Based on the outcome of such reseachs and arguments, the following hypothesis is formulated:

H8: Accountability is positively associated with performance

\section{RESEARCH METHODS}

This study used a mixed methods approach to answer our research question. One of the mixed method designs used in this study was the explanatory sequantial. This is a design of the mixed method that allows a researcher to collect data through two phases: the quantitative and qualitative phases (Creswell and Clark, 2011). The first phase involves the collection and analysis of quantitative data obtained through surveys using research instruments. Then, based on the results of the quantitative analysis, the researcher implements the second phase, the collection and analysis of qualitative data obtained through semi-structured interviews to explain the initial findings and explore in greater depth the information given by the respondents.

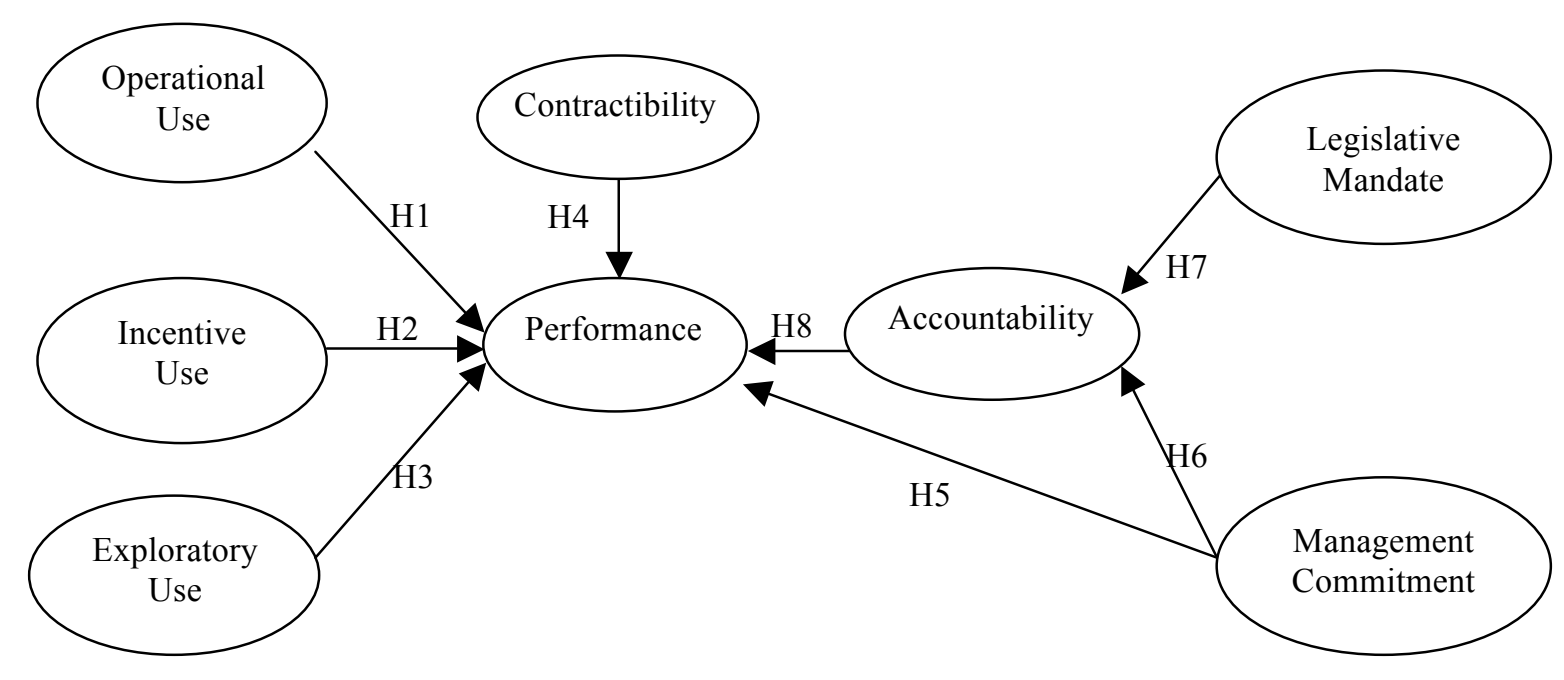

Figure 1. Research Proposed Model 


\section{Sample}

The study was conducted in the Province of Yogyakarta (DIY). The object of this study were the senior executive officers at the work units (SKPD) in five districts/cities in DIY. The sampling method used is a purposive sampling with the minimal criteria that the officers be at least in the fourth echelon, have responsibilities and adequate experience and have been involved in the organization's strategic planning process and the preparation of performance reports, and are believed to understand the situation and condition of the environmental organization. These samples in DIY were chosen because the performance of governance in this province occupies the top position in the rankings, and is the best among all the other provinces, and the performance was above the national average with a value of 6.80 (Indonesia Governance Index, 2013). Audit results also showed good performance which was reflected in the Local Government Financial Statement (LKPD) which received an unqualified opinion (WTP) for four of the six existing LKPDs in DIY (BPK, 2014).

\section{Operational Definition and Variables Measurement}

Performance. The performance variable is an endogenous variable, which is measured using an instrument of Spekle and Verbeeten (2014) and was developed previously by Van de Ven and Ferry (1980). The instrument is specifically designed to measure the performance of public sector organizations and has been used in several previous studies, such as the study by Williams et al. (1990), Dunk and Lysons (1997), Verbeeten (2008), and Spekle and Verbeeten (2014). The performance dimensions include: (1) productivity, (2) quality or accuracy of the work produced, (3) number of innovations, process improvements, or new ideas, (4) reputation for work excellence, (5) attainment of production or service level goals, (6) efficiency of operations, and (7) morale of the unit's personnel.
Accountability. Based on the study of Akbar et al. (2012), accountability consisted of two concepts: internal and external accountability. Internal accountability is a type of direct accountability that applies to a particular organization's systems and involves direct reporting by subordinates to their superiors who hold power. External accountability is an indirect type of accountability that involves reporting to outside organizations (Matek, 1977 as cited by Akbar, 2011). The instrument was adopted from Cavalluzzo and Ittner (2004), Akbar et al. (2012) and Wang (2002) with some adjustments based on the context of Indonesia.

The Use of a Performance Measurement System. This variable is an exogenous variable that includes operational use, incentives use, and exploratory use. The variable was measured using various categories of performance metrics for a particular purpose. The categories consisted of input measures, process measures, output measures, quality measures, and outcome measures (Spekle and Verbeeten, 2014). The instrument was adopted from Spekle and Verbeeten (2014).

Contractibility. The contractibility variables are exogenous variables and were adopted from the study of Spekle and Verbeeten (2014), they are a formative construct and include three indicators: (1) the clarity of the organization's mission and goals, (2) the measurability of outputs in terms of achieving the goals, and (3) knowledge of the transformation process. The three indicators were measured using a 1-5 Likert scale consisting of item related questions within this construct. Items questioned in the questionnaire were adopted from Spekle and Verbeeten (2014), Verbeeten (2008) and Withey et al. (1983).

Management commitment. The management commitment variable was used to measure how intensively official public sector organizations were committed to improving accountability and organizational performance. This variable is an exogenous variable and the question items refer to the instrument of 
Cavalluzzo and Ittner (2004) and Nurkhamid (2008).

Legislative mandate. The legislative mandate is associated with the involvement of subordinates and superiors in activities which relate to the performance accountability reports by government agencies. This variable is an exogenous variable and was measured using the measurement instrument of Akbar et al. (2012).

\section{Data Analysis Methods}

The quantitative data were analyzed using a variety of inferential statistical tests such as a validity test, reliability test, descriptive statistics, and multivariate analysis. Hypotheses were tested using the SEM-PLS approach with WarpPLS 3.0 software. SEM-PLS was used because it was able to test several dependent and independent variables simultaneously (Gudono, 2012; Akbar, 2011; Barclay et al., 1995). SEMPLS can also estimate the model with a relatively small sample size, does not require the fulfillment of assumptions such as normality and goodness of fit models, and can be done without a strong theoretical basis (Latan and Gudono, 2013; Sholihin and Ratmono, 2013). Evaluation of the PLS model is done by evaluating the measurement model and the structural model. The qualitative phase of this study was the second phase, which involved the investigation and exploration of respondent answers or experiences through semi-structured and open interviews. Qualitative data was analyzed using a thematic content analysis. This is a method for identifying, analyzing, and reporting patterns (themes) in a group of data (Braun and Clarke, 2006). Qualitative data was collected from the transcripts of the interviews that were held with the respondents, or from other texts that could explain the research topic.

\section{ANALYSIS AND RESULTS OF THE STUDY}

\section{Quantitative Analysis}

Pilot study. A pilot study was conducted before the research instrument was sent to the actual respondents. The pilot study was carried out on 32 local government officials who were studying in the Master of Economics Development (MEP) programme of the Faculty of Economics and Business, Universitas Gadjah Mada. The data were analyzed using WarpPLS software version 3.0. Analysis of the data was required for the validity construct criteria with a loading factor greater than 0.70 , but a loading factor of between $0.40-0.60$ was still considered, while a loading factor under 0.40 was excluded. The result of the validity test showed that there were two items which had a loading factor under 0.40 , and these items were then immediately removed from the research instrument (two items of contractibility constructs). In addition, reliability testing should also have met a minimum requirement of 0.60 as indicated from the composite reliability values and Conbach's alpha. The results showed that all the criteria of validity and reliability have met the requirement, and the questions were reasonable for further use.

Quantitative Data Collection. Quantitative data was conducted through a survey by sending questionnaires to each SKPDs district/city in the DIY. The survey was conducted starting on November the $5^{\text {th }}$ to December the $8^{\text {th }}, 2014$. The number of questionnaires sent out were 184 , and 146 questionnaires were returned for a response rate of 79.3 percent. However, nine of the returned questionnaires were not filled in completely and were excluded from the analysis so only the remaining 137 questionnaires could be analyzed for an effective response rate of 93.8 pecent. The number of questionnaires returned that could be analyzed provided an overview of the demographic profile of the respondents and is shown in Table 1 below.

Non-Response Bias. The quantitative data collection took approximately one month, so to ensure there was no non-respone bias from the respondents from the time differences in returning the questionnaires, a Mann-Whitney test was carried out to make sure that there was no difference among the initial and final responses. The test results showed that for all the variables used between the 80 initial responses and the 57 final responses, there was no 
difference, with the significance score above five percent $(>0.05)$. The Mann-Whitney test gave the following results for each variable: performance (0.346), contractibility (0.371), accountability (0.858), legislative mandate (0.928), commitment management (0.506), operational use (0.075), incentive use (0.111), and exploratory use (0.638). Furthermore, a Kruskal-Wallis test was used to ensure no differences among the sampling regions. This test is necessarily because the data were obtained from various different regions including five districts/cities in DIY (Yogyakarta, Bantul,
Gunung Kidul, Kulon Progo, and Sleman). The test results show that all the variables for each region have a significance value above 0.05 . This result concludes that there was no difference among the five sampling regions in this study.

Hypotheses testing. The hypotheses were tested using SEM-PLS with a bootstrapping function in WarpPLS software. Before testing the hypotheses, the measurement model in SEMPLS was evaluated first, to test the validity and reliability of construct.

Table 1. Demographic Profile of Respondents ( $\mathrm{N}=137)$

\begin{tabular}{|c|c|c|c|c|c|}
\hline $\begin{array}{l}\text { Respondent } \\
\text { Characteristics }\end{array}$ & Amount & $\begin{array}{c}\text { Percentage } \\
(\%)\end{array}$ & $\begin{array}{l}\text { Respondent } \\
\text { Characteristics }\end{array}$ & Amount & $\begin{array}{c}\text { Percentage } \\
(\%)\end{array}$ \\
\hline \begin{tabular}{ll}
\multicolumn{2}{l}{ Gender } \\
- $\quad$ Male \\
- $\quad$ Female \\
- $\quad$ Missing
\end{tabular} & $\begin{array}{l}72 \\
51 \\
14\end{array}$ & $\begin{array}{l}52.6 \% \\
37.2 \% \\
10.2 \%\end{array}$ & $\begin{array}{ll}\text { Level of Education } \\
\text { - } & \text { High School } \\
\text { - } & \text { Diploma } \\
\text { - } & \text { Graduate } \\
\text { - } & \text { Postgraduate } \\
\text { - } & \text { Doctor } \\
\text { - } & \text { Missing }\end{array}$ & $\begin{array}{c}1 \\
6 \\
66 \\
49 \\
1 \\
14\end{array}$ & $\begin{array}{r}0.7 \% \\
4.4 \% \\
48.2 \% \\
35.8 \% \\
0.7 \% \\
10.2 \%\end{array}$ \\
\hline $\begin{array}{ll}\text { Position } \\
\text { - } & \text { Echelon II } \\
\text { - } & \text { Echelon III } \\
\text { - } & \text { Echelon IV } \\
\text { - } & \text { Missing }\end{array}$ & $\begin{array}{c}4 \\
36 \\
79 \\
18\end{array}$ & $\begin{array}{r}2.9 \% \\
26.3 \% \\
57.7 \% \\
13.1 \%\end{array}$ & $\begin{array}{ll}\text { Experience } \\
\dot{\bullet} & <2 \\
\cdot & 2-5 \\
\cdot & 6-10 \\
\cdot & 11-15 \\
\cdot & >15 \\
\cdot & \text { Missing }\end{array}$ & $\begin{array}{c}- \\
3 \\
4 \\
16 \\
100 \\
14\end{array}$ & $\begin{array}{r}- \\
2.2 \% \\
2.9 \% \\
11.7 \% \\
73 \% \\
10.2 \%\end{array}$ \\
\hline $\begin{array}{ll}\text { Age } \\
: \quad<30 \\
\cdot \quad 30-40 \\
\cdot \quad 41-50 \\
\cdot \quad>50 \\
\cdot \quad \text { Missing }\end{array}$ & $\begin{array}{c}4 \\
15 \\
63 \\
40 \\
15\end{array}$ & $\begin{array}{r}2.9 \% \\
11 \% \\
46 \% \\
29.2 \% \\
10.9 \%\end{array}$ & 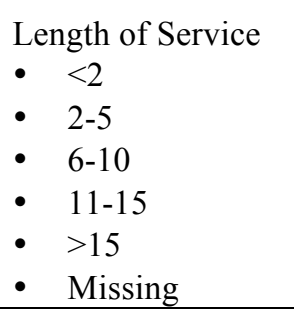 & $\begin{array}{c}38 \\
61 \\
11 \\
5 \\
3 \\
19\end{array}$ & $\begin{array}{r}27.7 \% \\
44.5 \% \\
8 \% \\
3.7 \% \\
2.2 \% \\
13.9 \% \\
\end{array}$ \\
\hline
\end{tabular}

Table 2. Correlation Among Latent Variables

\begin{tabular}{lcccccccc}
\hline & 1 & 2 & 3 & 4 & 5 & 6 & 7 & 8 \\
\hline 1. Perf & $\mathbf{0 . 7 5 5}$ & 0.251 & 0.316 & 0.127 & 0.306 & 0.463 & 0.347 & 0.414 \\
2. OU & 0.251 & $\mathbf{0 . 9 1 2}$ & 0.705 & 0.329 & 0.422 & 0.534 & 0.581 & 0.716 \\
3. EU & 0.316 & 0.705 & $\mathbf{0 . 8 2 7}$ & 0.338 & 0.514 & 0.531 & 0.610 & 0.696 \\
4. Leg & 0.127 & 0.329 & 0.338 & $\mathbf{0 . 9 6 2}$ & 0.095 & 0.255 & 0.386 & 0.407 \\
5. IU & 0.306 & 0.422 & 0.514 & 0.095 & $\mathbf{0 . 9 3 4}$ & 0.306 & 0.317 & 0.458 \\
6. Com & 0.463 & 0.534 & 0.531 & 0.255 & 0.306 & $\mathbf{0 . 8 1 5}$ & 0.710 & 0.692 \\
7. Cont & 0.347 & 0.581 & 0.610 & 0.386 & 0.317 & 0.710 & $\mathbf{0 . 8 9 1}$ & 0.636 \\
8. Acc & 0.414 & 0.716 & 0.696 & 0.407 & 0.458 & 0.692 & 0.636 & $\mathbf{0 . 8 7 7}$ \\
\hline
\end{tabular}

Source: Output Warp-PLS (2015)

Note: Square root of AVE showed on diagonal. 
The validity test in this study consisted of the convergent validity (see Table 3 ) which can be seen from the loading value, which must be greater than 0.50 with a p-value of $<0.05$, and the discriminant validity (see Table 2 ) which can be measured by seeing that the square root of AVE is greater than the correlation between the construct and the loading indicator, when the construct being measured is greater than the loading for the other constructs (low crossloadings) (Hair et al., 2006; Akbar, 2011; Sholihin and Ratmono, 2013). While the reliability test was assessed using two methods,
Cronbach's alpha and the composite reliability (see Table 4), which must be greater than 0.70 , even though a value of 0.60 is acceptable (Hair et al., 2010; Sholihin and Ratmono, 2013). The results of the validity and reliability test showed that all the criteria met the requirements so that the data from the instrument were fit for use in further analyzes.

The structural model in PLS was evaluated by using the coefficient of determination $\left(\mathrm{R}^{2}\right)$ and Q-Squared. The results are shown in Table 4 below.

Table 3. Convergent Validity

\begin{tabular}{|c|c|c|c|c|c|c|c|}
\hline Variables & Items & Loading* & P-Value & Variables & Items & Loading* & P-Value \\
\hline \multirow{3}{*}{$\mathrm{OU}$} & OU1 & 0.904 & $<0.001$ & \multirow[t]{3}{*}{ Leg } & Leg1 & 0.962 & $<0.001$ \\
\hline & OU2 & 0.933 & $<0.001$ & & Leg2 & 0.962 & $<0.001$ \\
\hline & OU3 & 0.899 & $<0.001$ & & & & \\
\hline \multirow{3}{*}{ IU } & & & & \multirow{9}{*}{ ExAcc } & ExAcc1 & 0.846 & $<0.001$ \\
\hline & IU1 & 0.934 & $<0.001$ & & ExAcc 2 & 0.863 & $<0.001$ \\
\hline & IU2 & 0.934 & $<0.001$ & & ExAcc3 & 0.896 & $<0.001$ \\
\hline \multirow{6}{*}{ EU } & & & & & ExAcc4 & 0.888 & $<0.001$ \\
\hline & EU1 & 0.745 & $<0.001$ & & ExAcc5 & 0.903 & $<0.001$ \\
\hline & EU2 & 0.865 & $<0.001$ & & ExAcc6 & 0.869 & $<0.001$ \\
\hline & EU3 & 0.834 & $<0.001$ & & ExAcc7 & 0.813 & $<0.001$ \\
\hline & EU4 & 0.838 & $<0.001$ & & ExAcc8 & 0.808 & $<0.001$ \\
\hline & EU5 & 0.850 & $<0.001$ & & & & \\
\hline \multirow{8}{*}{ Perf } & & & & \multirow{8}{*}{ Clear } & Clear1 & 0.836 & $<0.001$ \\
\hline & Perf1 & 0.748 & $<0.001$ & & Clear2 & 0.877 & $<0.001$ \\
\hline & Perf2 & 0.781 & $<0.001$ & & Clear3 & 0.862 & $<0.001$ \\
\hline & Perf3 & 0.793 & $<0.001$ & & Clear4 & 0.864 & $<0.001$ \\
\hline & Perf4 & 0.701 & $<0.001$ & & Clear5 & 0.806 & $<0.001$ \\
\hline & Perf5 & 0.785 & $<0.001$ & & & & \\
\hline & Perf6 & 0.780 & $<0.001$ & & Meas 1 & 0.724 & $<0.001$ \\
\hline & Perf7 & 0.694 & $<0.001$ & & Meas2 & 0.526 & $<0.001$ \\
\hline \multirow{7}{*}{ Com } & & & & \multirow{6}{*}{ Meas } & Meas3 & 0.803 & $<0.001$ \\
\hline & Com 1 & 0.776 & $<0.001$ & & Meas4 & 0.840 & $<0.001$ \\
\hline & Com2 & 0.818 & $<0.001$ & & Meas5 & 0.837 & $<0.001$ \\
\hline & Com3 & 0.773 & $<0.001$ & & Meas6 & 0.812 & $<0.001$ \\
\hline & Com4 & 0.830 & $<0.001$ & & & & \\
\hline & Com5 & 0.865 & $<0.001$ & & Trans 1 & 0.758 & $<0.001$ \\
\hline & Com6 & 0.824 & $<0.001$ & \multirow[t]{6}{*}{ Trans } & Trans 2 & 0.706 & $<0.001$ \\
\hline \multirow{5}{*}{ InAcc } & & & & & Trans3 & 0.866 & $<0.001$ \\
\hline & InAcc1 & 0.718 & $<0.001$ & & Trans4 & 0.817 & $<0.001$ \\
\hline & InAcc 2 & 0.803 & $<0.001$ & & & & \\
\hline & InAcc 3 & 0.813 & $<0.001$ & & & & \\
\hline & InAcc 4 & 0.753 & $<0.001$ & & & & \\
\hline
\end{tabular}

* two items of management commitment construct (Com) have been dropped because they did not have the required loading score 0,50 .

Note: Perf $=$ Performance, InAcc $=$ Internal Accountability, ExAcc $=$ External Accountability, Leg $=$ Legislative Mandate, $\mathrm{Com}=$ Management Commitment, $\mathrm{OU}=$ Operational Use, $\mathrm{IU}=$ Incentive Use, and EU $=$ Exploratory Use, Clear = Clarity of mission and goals, Meas $=$ Measurability of output, Trans $=$ Knowledge of transformation process. 
Table 4. Latent Variables Coefficients

\begin{tabular}{lcccccccc}
\hline \multicolumn{1}{c}{ Coefficients } & Perf & OU & EU & Leg & IU & Com & Cont & Acc \\
\hline $\mathrm{R}^{2}$ & 0.258 & & & & & & & 0.535 \\
Composite reliability & 0.903 & 0.937 & 0.915 & 0.961 & 0.932 & 0.922 & 0.920 & 0.869 \\
Cronbach's alpha & 0.874 & 0.899 & 0.884 & 0.919 & 0.853 & 0.898 & 0.870 & 0.699 \\
AVE & 0.571 & 0.832 & 0.685 & 0.925 & 0.872 & 0.664 & 0.794 & 0.768 \\
Full collinearity VIFs & 1.352 & 2.552 & 2.692 & 1.294 & 1.469 & 2.748 & 2.554 & 3.431 \\
Q-squared & 0.240 & & & & & & & 0.533 \\
\hline
\end{tabular}

Source: Output Warp-PLS (2015)

Table 4 above shows that the endogenous variables of accountability have a coefficient of determination $\left(\mathrm{R}^{2}\right)$ of 0.535 . These results indicate that the variance of the endogenous variables of accountability of 53.5 percent can be explained by the variance of the exogenous variables, that is the legislative mandate and management commitment. While the endogenous variable of performance has a coefficient of determination $\left(\mathrm{R}^{2}\right)$ of 0.258 , which means that this variable is only able to be explained by the exogenous constructs of 25.8 percent, which means it is very weak. Furthermore, the relevance of the predictive in the research models was reflected by the Q-Squared value. This value must be greater than zero, which indicates that the exogenous latent variables have predictive relevance to the endogenous latent variables that influence them (Sholihin and Ratmono, 2013). The Q-Squared values shown in Table 5 are 0.240 for the performance variable and 0.533 for the accountability variable, which means that the predictive relevance of this research model is good.
Meanwhile, the results of the hypotheses testing are determined by seeing the path coefficients, standard errors, $p$-values, and effect sizes. Details of the hypotheses testing results are shown in Table 5. The results testing of hypothesis 1 in Table 5 shows that the path coefficient of OU $\rightarrow$ Perf is -0.011 , the p-value is $0.466(>0.05)$, and the effect size is 0.003 . While hypothesis 2 is shown by the path coefficient of Perf $\rightarrow$ IU being 0.151 , the pvalue is $0.101(>0.05)$, and the effect size is 0.048 . Furthermore, hypothesis 3 is shown by the path coefficient of EU $\rightarrow$ Perf being -0.047 , the p-value is $0.394(>0.05)$, and the effect size is 0.015 . The results testing of hypotheses 1,2 , and 3 indicate that the three roles which the performance measurement systems are used for (operational, incentives, and exploratory), which were predicted to have a relationship with organizational performance, are not empirically confirmed, which is reflected from the p-values being greater than 0.05 , so that hypotheses 1,2 , and 3 are not supported.

Table 5. Hypotheses Test Result

\begin{tabular}{lcccc}
\hline & Path Coefficients & P-Values & Standard errors & Effect sizes \\
\hline OU ---> Perf & -0.011 & 0.466 & 0.125 & 0.003 \\
IU ---> Perf & 0.151 & 0.101 & 0.118 & 0.048 \\
EU ---> Perf & -0.047 & 0.394 & 0.174 & 0.015 \\
Cont ---> Perf & 0.064 & 0.329 & 0.143 & 0.024 \\
Leg ---> Acc & 0.220 & $0.003^{* *}$ & 0.079 & 0.095 \\
Com ---> Acc & 0.628 & $<0.001^{* * *}$ & 0.065 & 0.440 \\
Com ---> Perf & 0.291 & $0.030^{*}$ & 0.153 & 0.137 \\
Acc ---> Perf & 0.139 & 0.156 & 0.137 & 0.062 \\
\hline
\end{tabular}

Source: Output Warp-PLS (2015)

* Significant at 0.05 level (2-tailed)

** Significant at 0.01 level (2-tailed)

*** Significant at 0.001 level (2-tailed) 
The hypothesis 4 that predicted the existence of a positive relationship between contractibility and organizational performance is also not empirically confirmed. It can be seen that the path coefficient of Cont $\rightarrow$ Perf is 0.064 , the pvalue is $0.329(>0.05)$, and the effect size is 0.024 . These results indicate that hypothesis 4 was not supported. Furthermore, testing of hypothesis 5 shows the path coefficient of Leg $\rightarrow$ Acc is 0.220 , the p-value is $0.003(<0.05)$, and the effect size is 0.095 . This results support the hypothesis that the legislative mandate was positively associated with accountability. However, the value of the effect size indicates it is relatively weak, as expressed by Sholihin and Ratmono (2013) who categorized the effect size into three groups: weak (0.02), medium (0.15), and substantial (0.35). The testing of hypothesis 6 regarding the relationship between commitment management and accountability was shown by the path coefficient of Com $\rightarrow$ Acc being 0.628 , the $p$-value is $<0.001$, and the effect size is 0.440 . These results indicate that management commitment was positively associated with accountability and support the hypothesis. Similar results were also found in hypothesis 7 , that management commitment was positively associated with organizational performance. It is shown from the value of the path coefficients of Com $\rightarrow$ Perf being 0.291, the p-value is 0.030 $(<0.05)$, and the effect size is 0.137 . So hypothesis 7 was also empirically confirmed. Finally, the results testing of hypothesis 8 which predicted a positive relationship between accountability and organizational performance has not been empirically confirmed. It can be seen that the path coefficient Perf $\rightarrow$ Acc is 0.139 , the $p$-value is $0.156(>0.05)$, and the effect size is 0.062 . These results indicate that accountability was not positively associated with organizational performance.

\section{Qualitative analysis}

Qualitative Data Collection. Creswell and Clark (2011) revealed that one way to select a sample of interviewees is to select the outliers of the data's distribution from the results of the quantitative data analysis. Here the spread of the results of the quantitative data processing indicated that the outlier data could be found using a scatter plot graph (Figure 2).

From the figure above, it can be seen that the points which are spread far from the group of data are outliers. Then, the data were identified by adjusting the number of respondents to the questionnaire to see whether the outliers who provided the data were willing to be interviewed. From this identification, five respondent outliers were fit and willing to be interviewed, so the five respondents were used as the sample. The sample consisted of two respondents from echelon III and three respondents from echelon IV, and these five people were spread across three regions (Sleman, Bantul, and Yogyakarta).

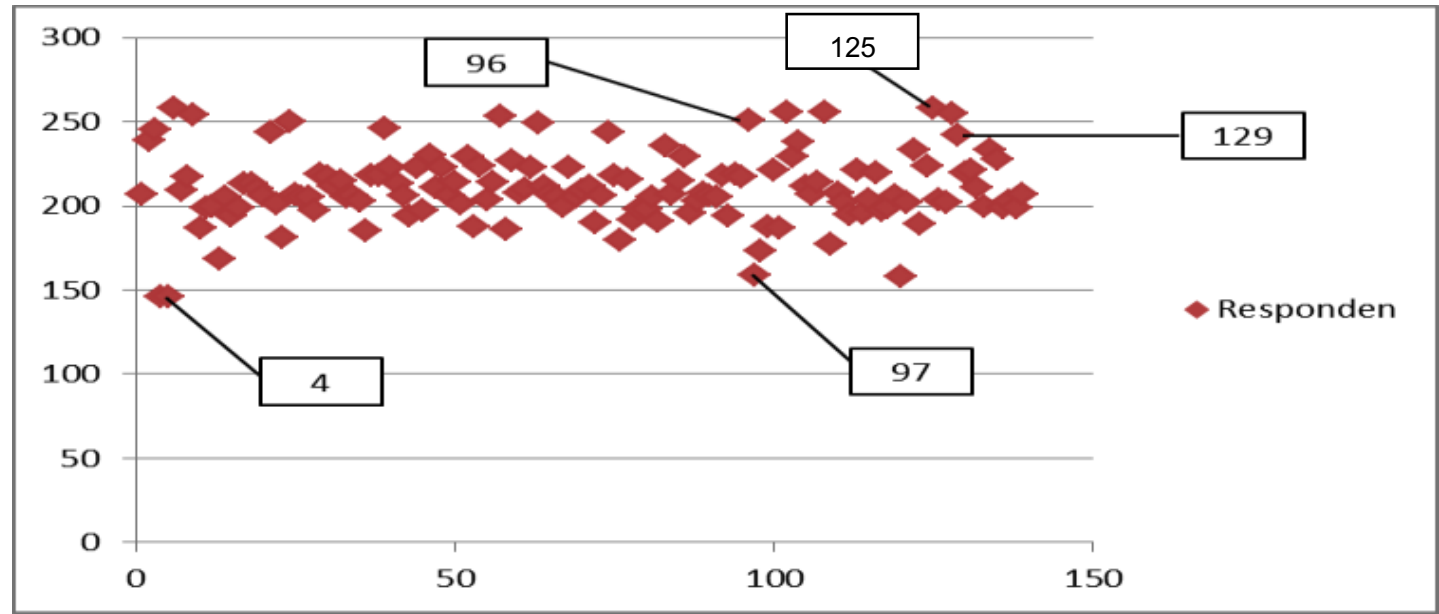

Source: Output of the outcome of excel-managed data (2015)

Figure 2. Scatter Plot Graph 
There were three men and two women involved in these interviews. The interviews were carried out face-to-face and took around 20-30 minutes each. The interviews were recorded using a voice recorder once permission was obtained from the interviewee.

Qualitative Data Analysis. The qualitative data were analyzed using a thematic content analysis. The main themes raised to obtain this qualitative data were associated with the threedimensional isomorphism (coercive, mimetic, and normative) in the institutional theory as expressed by DiMaggio and Powell (1983). In simple language, a coercive isomorphism refers to the pressure faced by an organization to change or take action; a mimetic isomorphism refers to the organization that mimics other organizations because of uncertainty; and a normative isomorphism refers to the norms or cognitive understanding of professionals. The three main themes became a guide to creating a list of relevant questions to investigate the possibility of isomorphic pressure during the process of performance measurements and reporting, as well as for the accountability practices in government agencies. The results of this thematic content analysis, based on the evidence obtained from our interviews with the respondents are described in more detail below:

\section{Coercive isomorphism}

It was revealed, based on the thematic content analysis of the transcripts of the interviews, that government officials while fulfilling their duties, both in terms of performance assessment, performance reporting, and enhancing performance and accountability, were driven by regulations and rules. This can be seen from the comments of the following respondents:

In our management, we always work based on the rules, so if it is associated with regulations concerning the improvement of performance, it is obviously very tight, very supportive, because it becomes part of our guidance for our work. Our position is clear right now, that it must be determined in accordance with the rules. For example, in the financial field, there is a term, namely
DPA (document for budget implementation), it is the key, our employment contract. So that with regard to the rules that relate to the performance improvement, it is clearly impacted (R127, Secretary of Sub-District).

... that's what regulations provides us, as actors of governance processes, a roadmap. For example, how the instructions regarding the use of money, such as, in the procurement of goods and services, financial administration, and then the management of services, there are three. All of the three programs provide us with the roadmap, step by step, what must be done. It gives us certainty. So psychologically, we have an uncontested guidance in the form of regulations. With the certainty that it's uncontested (in the process usually there are issues, including conflict of interests, intervention by the employer, and others), because we have the rules, it gives us a sense of psychological safety to implement it, so as no doubt, automaticly the efficiency levels of execution become faster in time, and its output can be guaranteed. (R4, Sub Head of Reseach \& Development, Socio-Cultural, and Economy).

Based on those comments, it is clear that institutional isomorphism in the form of coercive pressure occurs in the practice of the implementation of performance measurement and accountability in the public sector organizations (government agencies) in DIY. This is in line with what was expressed by Brignall and Modell (2000), that the rules and regulation are a legislative mandate, and one of the relevant factors for the successful implementation of reforms in government organizations. Talbot (2008) also revealed the same thing, that public managers assess the law as one of the main drivers of a change. Coercive pressure in the form of this regulation is fair, because most government organizations in Indonesia have a dependency on the central government, in the form of financial resources or through a system of rewards (Akbar et al., 2012). There are no other options for the local governments and agencies, except to comply with the rules and report their perfor- 
mance in order to keep getting their funding through the budget allocations of the central government.

\section{Mimetic Isomorphism}

DiMaggio and Powell (1983) revealed that mimetic isomorphism arises as a result of a process to respond to the uncertainty of the environment in the area where the organization operates. When the organization has a low level of technology, organizational goals are not clear and very ambiguous, or even the organizational environment creates symbolic uncertainty, then the organization may be modelling itself to resemble the shape of other organizations (DiMaggio and Powell, 1983). Results from the interviews with respondents have strengthened the research of DiMaggio and Powell (1983), in that the government agencies, especially the SKPDs in the local government of Yogyakarta watch and refer to other agencies when making a performance report, in an attempt to meet the regulatory requirements.

In making a performance report, we refer to the local government, and there is coordination between the agencies and it is coordinated by BAPPEDA (R125, Head of Labour).

So far, the reporting formats at the SKPDs level are not clear, they require templates to be developed for the SKPDs level (R96, Sub Head of Planning and Reporting).

Based on above comments, it is clear that there is no definate reporting format at the SKPDs level for making performance reports. This is one of the reasons why government institutions imitate or refer to other agencies' reporting formats, and at the same time strengthen the evidence of mimetic isomorphism in the performance of their reporting practices. In addition, many emerging regulations cause overlapping or even contradictions between the rules which then leads to confusion for the government actors (officials) who are trying to implement the rules. Thus, what happens is they follow or imitate other organizations in making their performance reports.

\section{Normative isomorphism}

Normative pressures in the context of the public sector organizations usually come from professional groups, such as consultants or college through a variety of conferences, seminars, workshops, training, and mentoring. The role of these professional groups is crucial for organizations in order to reduce their errors and to increase their chances of success in their performance reporting and accountability (Akbar et al., 2012; Han and Koo, 2010). One of the professional institutions, who have such a role and help the government agencies is the Development and Financial Supervisory Agency (BPKP).

Yes there is help, from BPKP and from MENPAN. The assistance that they provide such as advocacy assistance, workshop, and they gives theories, and the participants can practice directly. The assistance is done usually once a year at the time of going to compile the report, then the coordinator makes a request with the names of the team, so each of the people can get training on LAKIP (R97, Sub Head of Job Analysis and Apparatus)."

In our agencies there is a final evaluation at the level of the SKPD, and later we asked for consideration or suggestions for each field and department, for the preparation of materials and the performance evaluation during the year, such as workshops" (R96, Sub Head of Planning and Reporting)

I am involved in HEPI (Association of Indonesian Education Evaluator), as an assessor in the excellent schools, to assess the feasibility evaluation process at the excellent schools. If LAKIP, we consult on the report with the Tata Pemerintahan, if such an arrangement of the report was appropriate or not, what needs to be altered or re-done, we consult with the Tata Pemerintahan in the local secretariat (R96, Sub Head of Planning and Reporting).

In addition, government agencies also use consultants from universities in the process of program planning. This is done in order to obtain 
optimal results. Universities are seen as institutions that have the required knowledge and also excellent academic qualifications, which are expected to assist the organization in the management practices of the government agencies. This fact is true, according to the results of research interviews with government officials.

In the planning-namely workforce planning of Sleman district, this program was helped by consultants from UGM. Not only that, the Sleman district became a pilot project for the SMART City, the city based IT city construction whose consultants came from ITB. In Indonesia there are seven cities that became pilot projects. In Sleman, this project was handled by BAPPEDA, we only helped the project because we do IT, such as card services AK 1 (yellow card), our service has been ISO 90012008 certified (R125, Head of Labor).

Thus, it is clear that public sector organizations, especially those in the local government of Yogyakarta Province obtain great benefit from professional groups such as the BPKP or the universities, in the practice of their performance measurements and accountability of their organizations. So this condition strengthens the evidence that the normative isomorphism also occurs in the process of an organization trying to get the best practices for its management of the organization. Evidence of the normative isomorphism in the reporting of the performance of government agencies is also found in previous studies by Akbar et al. (2012).

\section{CONCLUSION AND DISCUSSION}

The results of the quantitative and qualitative analyses found strong evidence for the influence of management commitment as one of the organizational factors that have an impact on the accountability and performance of public sector organizations. Management commitment is a form of normative isomorphism which is necessary for organizations. Public sector managers are required to give reasons and be responsible to the public for their utilization of public resources. This finding was consistent with many we found in the literature that said that management commitment can affect the performance improvement (Sholihin and Pike, 2009), the development of performance indicators, the use of performance information, and the performance accountability (Cavalluzzo and Ittner, 2004; Primarisanti, 2013), as well as the internal and external accountability (Akbar et al., 2012). This result was also confirmed by the following respondents comments:

Management commitment at the top management level, in the management control system there is usually a term 'turn of the top'. So the leaders who will maintain and regulate the rhythm of the organization which is carrying out the task, would take it quickly, then go slowly, then go straight, because of 'turn of the top' (R127, Secretary of Sub-District).

Furthermore, the results of this study also found evidence that the legislative mandate has a positive association with accountability. Our findings suggest that the pressure, in the form of regulations from the central government, is still quite strong despite the decentralization that has been on-going for more than a decade. The legislative mandate is a form of coercive isomorphism which is considered to be one aspect of the successful implementation of reforms in the public sector organizations in Indonesia, especially in the local government of DIY. The results of the qualitative data analysis also found the mimetic isomorphism in actual practice. This finding was evident from government agencies, especially the SKPDs, which referred to other agencies in making their performance reports in an attempt to meet the regulatory requirements. These findings lead to the conclusion that institutional isomorphism is really happening in actual everyday practices and plays a strong role in the implementation process of the performance measurement systems and accountability of the public sector organizations, especially the SKPD.

Meanwhile, contrary to our hypothesis, the use of performance measurement systems for operational and exploratory purposes have a negative impact on performance. This indicates 
that the operational roles that are commonly used in organizations as a basic requirement (Hansen and Van der Stede, 2004; Spekle and Verbeeten, 2014) are actually only a formality in the performance of work obligations. The role does not have a special purpose designed to improve performance and the achievement of organizational outcomes. These were reinforced by the statement of the following respondents:

Actually it never happened (using existing information in LAKIP), which occurred as just a formality. So actually, LAKIP must report in a timely manner, using the appropriate formats, in accordance like this, like that, report to DEPDAGRI (Department of the Interior), to BAPPENAS (National Development Planning Agency), but in reality it is just reported, the information is not used for anything. Whether the achievement of Minimum Service Standards (MSS) should be so, be meaningful, sometimes did not anyway. For example, we have data, from year to year, the percentage of homes that are not licensed, since the existing licensing agency was created, but instead of going down, the percentage rises. It means that the data, the report, was not used for anything by the government, no action taken, it should get action to make it clear (R4, Sub Head of Reseach \& Development, Socio-Cultural, and Economy).

Furthermore, in regarding the role of exploratory use, it requires a search value and higher learning to improve performance (Abernethy and Brownell, 1999). When additional insights into the process of improving decision-making and resource allocation does not exist, then the tendency to be able to improve the performance reduces. The role of exploratory use requires top management's time, broad organizational involvement and increased interaction among the members of the organization (Simons, 2000 in Speke and Verbeeten, 2014), as well as communication strategies to eliminate ambiguity and confusion about the organizational goals (Spekle and Verbeeten, 2014).

Besides, different results were also found in the use of performance measurement systems for incentive-oriented schemes, which had a very weak relationship with performance. This result was consistent with Spekle and Verbeeten (2014), that the effect of incentives on performance will be high when there is high contractibility (i.e clear goals, performance/ outputs that are measurable, and knowledge of the transformation process). This indicates that in order to improve performance and promote efficiency and effectiveness in public sector organizations, we need a mechanism of performance contracting in which the performance targets can be clear and measurable in order that the government actors can achieve the organizational goals (Spekle and Verbeeten, 2014). This mechanism is important for aligning incentives and performance. It is also reinforced by the comments of the following respondents:

We want to make it (the system of incentives related to employee performance), we have created the system. So what a person does earns points, then for the points that we set there is an incentive (Rupiah). Thus, in a period such as a month, an employee can accumulate reward points and later can get many Rupiah. But this time is not yet, we are making the system, later in 2015 we will test it, if the result is good, then the policy decision-making is determined by our top management (R97, Sub Head of Job Analysis and Apparatus).

The performance is related to the person, not the leadership, so cherish the human, cherish the person. During this time, our personnel management system has never give the opportunity for personnal achievements. For example, riding position is four years in once, but how to get that position is not clear, you must be close to who, or capable of what is also not clear. The system should be made clear (R4, Sub Head of Reseach \& Development, Socio-Cultural, and Econo$m y$ ).

With regard to contractibility, this study found no association between contractibility and performance. This result may have occurred because, in the context of public sector organizations, government officials or actors cannot 
fully determine the satisfactory performance attributes. This happens because the managers' systematic influence on the ultimate outcome was restricted or unknown (Spekle and Verbeeten, 2014). If the organizations were unable to specify or define what they want from their managers, performance metrics cannot provide much guidance, and management control becomes political control (Hofstede, 1981).

Similar results were also found in the relationship between accountability and performance, which did not have a significant effect. Some literature still indicates a debatable influence of accountability on performance, but it is inconclusive. This is because performance itself is complex, multi-faceted, and difficult to measure (Demirag and Khadaroo, 2011; Hyndman and Eden, 2001). Moreover, accountability in the public sector organizations is probably not uniformly understood by the government officials as well as civil society. It is because accountability has many dimensions and can be defined from various perspectives (Sinclair, 1995).

\section{Implication}

This study provides some interesting contributions and implications to the academic literature and practices. First, theoretically, the institutional isomorphism, as one of the parts of the institutional theory used in this study, was recognized as a basic framework that was able to explain the implementation practices of performance measurement systems and accountability in public sector organizations, especially at the local government level in DIY. Second, methodologically, the use of mixed methods research by combining two approaches (quantitative and qualitative) were of great benefit and provided a robustness in the results. This approach was able to answer complex research problems and could explain various things and situations in more detail than just one approach.

Finally, this study has practical implications for the actors of public sector organizations, that performance measurement systems are an important component in the structure of the management control system. Public sector mana- gers need to consider various aspects in order to achieve efficiency and effectiveness in their organizations, for example, what to measure, how to measure it, and also how they should use the performance information related to conditions encountered in the field. Public sector organizations also need to pay greater attention to the commitment of member organizations, especially the top managements' commitment. This is because the managements' commitment provides a great contribution to the improvement of performance and accountability. In addition, policy makers need to increase their efforts to encourage government agencies to improve the accountability and performance of public services in order to realize their effectiveness and social welfare.

\section{Limitations and Suggestions}

As with other empirical studies, this study has some weaknesses and limitations. Firstly, the study was conducted only on public sector organizations in Yogyakarta, which limited the scope of the SKPD. Further research should enlarge their population areas and expand the scope of the public sector organizations, not only for the SKPD, but also other public sector organizations that provide public services such as hospitals and educational institutions. Secondly, the accountability variable in this study was defined only by internal and external accountability. However accountability can be defined in many dimensions, such as: political accountability, public accountability, managerial accountability, professional accountability, and personal accountability (Sinclair, 1995). Therefore, further research should identify the five dimensions of accountability, in relation to the organizational performance. Finally, this study did not explore to any great depth the hypotheses that were not supported, this is because the method used in this study only used an explanatory sequential design that aimed to capture the phenomena of isomorphism. Thus, further research could explore in more detail the information from respondents using other designs, such as exploratory, transformative, and triangulation. 


\section{REFERENCES}

Abernethy, M. A., and P. Brownell, 1999. "The Role of Budgets in Organizations Facing Strategic Change: An Exploratory Study." Accounting, Organizations and Society, 24, 189-204.

Akbar, R., 2011. "Performance Measurement and Accountability in Indonesian Local Government." Unpublished Dissertation, Australia: School of Accounting, Curtin University.

Akbar, R., R. Pilcher, and B. Perrin, 2012. "Performance Measurement in Indonesia: The Case of Local Government." Pacific Accounting Review, Vol. 24 (3), 262-291.

Ashworth, R., G. Boyne, and R. Delbridge, 2009. "Escape From the Iron Cage? Organizational Change and Isomorphic Pressures in the Public Sector." Journal of Public Administration Research and Theory, Vol. 19 (1), 165-87.

Badan Pengawasan Keuangan and Pembangunan, 2014. "Laporan Hasil Pengawasan atas Akuntabilitas Keuangan Negaral Daerah Tahun 2013 [Monitoring Reports on Financial Accountability Country/ Region 2013]." Available at: http://www. bpkp.go.id/public/upload/unit/diy/files/Files /Lapgub\%202013\%20final.pdf, accessed on September $12^{\text {th }}, 2014$.

Barclay, D., C. Higgins, and R. Thompson, 1995. "The Partial Least Squares (PLS) Approach to Causal Modelling: Personal Computer Adoption and Use as An Illustration." Technology Studies. Vol. 2 (2), 285-309.

Bovens, M., 2007. "Analyzing and Assessing Public Accountability. A Conceptual Framework." European Law Journal, 13 (4), 837-868.

Braun, V., and V. Clarke, 2006. "Using Thematic Analysis in Psychology." Qualitative Research in Psychology, 3 (2), 77-101.

Brignall, S., and S. Modell, 2000. "An Institutional Perspective on Peformance Measurement and Management in the New Public Sector." Management Accounting Research, Vol. 11, 281-306.

Cavalluzzo, K. S., and C. D. Ittner, 2004.
"Implementing Performance Measurement Innovations: Evidence From Government." Accounting, Organizations and Society, 29 (3-4), 243-267.

Christensen, T., and P. Laegreid, 2014. "Performance and Accountability - A Theoretical Discussion and An Empirical Assessment." Public Organization Review, DOI 10.1007/s11115-013-0267-2.

Creswell, J. W., and V. L. P. Clark, 2011. "Designing and Conducting Mixed Methods Research." Second Edition. USA: Sage Publication.

Demirag, I., and I. Khadaroo, 2011. "Accountability and Value for Money: A Theoretical Framework for the Relationship in PublicPrivate Partnerships." Journal Management Government, 15, 271-296.

DiMaggio, P. J., and W. W. Powell, 1983. "The Iron Cage Revisited: Institutional Isomorphism and Collective Rationality in Organizational Fields." American Sociological Review, Vol. 48, 147-160.

Dubnick, M., 2005. "Accountability and the Promise of Performance in Search of the Mechanisms." Public Performance \& Management Review, Vol. 28 (3), 376-417.

Dunk, A. S., and A. F. Lysons, 1997. "An Analysis of Departmental Effectiveness, Participative Budgetary Control Processes and Environmental Dimensionality within the Competing Values Framework: A Public Sector Study." Financial Accountability \& Management 13, 1-15.

Gudono, 2012. "Analisis Data Multivariat [Multivariate Data Analysis]", $2^{\text {nd }}$ Edition. Yogyakarta: BPFE.

Hair JR, J. F., W. C. Black, B. J. Babin, and R. E. Anderson, 2010. "Multivariate Data Analysis." $7^{\text {th }}$ Edition. New Jersey: Prentice Hall.

Hair JR, J. F., W. C. Black, B. J. Babin, R. E. Anderson, and R. L. Tatham, 2006. "Multivariate Data Analysis." $6^{\text {th }}$ Edition. New Jersey: Prentice Hall.

Han, J., and J. Koo, 2010. "Institutional Isomorphism and Decoupling among Korean Firms: Adoption of Performance Compensation System." Korean Journal of Sociology, Vol. 44 (3), 27-44. 
Hansen, S. C., and W. A. Van der Stede, 2004. "Multiple Facets of Budgeting: An Exploratory Analysis." Management Accounting Research 15, 415-439.

Hansen, D. R., and M. M. Mowen, 2007. "Managerial Accounting." $8^{\text {th }}$ Edition, USA: Thompson South-Western.

Hofstede, G., 1981. "Management Control of Public and Non-for-profit Activities." Accounting, Organizations and Society, Vol. 6 (3), 193-211.

Hyndman, N., and R. Eden, 2001. "Rational Management, Performance Targets and Executive Agencies: Views from Agency Chief Executives in Northern Ireland." Public Administration, 79 (3), 579-598.

Ichniowski, C., K. Shaw and G. Prennushi, 1997. "The Effects of Human Resource Management Practices on Productivity: A Study of Finishing Lines." The American Economic Review 87, 291-314.

Indonesia Governance Index, 2013. "Kinerja Tata Kelola Provinsi Daerah Istimewa Yogyakarta [Governance Performance of Yogyakarta Province]", Available at: http://www.kemitraan.or.id/igi/documents/1 brfakta/diy.pdf, accessed on September 12 2014.

Iyoha, F.O., and D. Oyerinde, 2010. "Accounting Infrastructure and Accountability in Management of Public Expenditure in Developing Countries: A Focus on Nigeria." Critical Perspective on Accounting 21, 361-373.

Latan, H., and Gudono, 2013. "SEM Structural Equation Modelling Aplikasi Software TETRAD IV [SEM Structural Equation Modelling Application Software TETRAD $I V] ", 1^{\text {st }}$ Edition. Yogyakarta: BPFE.

Micheli, P., and L. Mari, 2014. "The Theory and Practice of Performance Measurement." Management Accounting Research 25, 147 156.

Newberry, S., and J. Pallot, 2004. "Freedom or Coercion? NPM Incentive in New Zealand Central Government Departments." Management accounting Research 15, 247-266.

Nurkhamid, M., 2008. "Implementasi Inovasi Sistem Pengukuran Kinerja Instansi Pemerintah [Implementation of Innovation Government Performance Measurement
System]", Jurnal Akuntansi Pemerintah, Vol. 3 (1), 45-76.

Pollitt, C., 2008. "Performance Blight and the Tyranny of Light? Accountability in Advanced Performance Measurement Regimes." Non-published paper, Ohio: Public Management Institute, Katholieke Universiteit Leuven.

Primarisanti, H., 2013. “Analisis Faktor-Faktor yang Mempengaruhi Pengembangan Sistem Pengukuran Kinerja, Akuntabilitas Kinerja, and Penggunaan Informasi Kinerja [Analysis of Factors Affecting the Development of Performance Measurement System, Performance Accountability, and Use of Performance Information]", Unpublished Thesis, Post-Graduate Program. Yogyakarta: UGM.

Schillemans, T., 2011. "Does Horizontal Accountability Work? Evaluating Potential Remedies for the Accountability Deficit of Agencies." Administration \& Society, 43 (4), 387-416.

Scott, W. R., 1995. "Institutions and Organizations." Thousand Oaks, CA: Sage.

Sholihin, M., and D. Ratmono, 2013. "Analisis SEM-PLS dengan WarpPLS 3.0 untuk Hubungan Nonlinier dalam Penelitian Sosial and Bisnis [Analysis of SEM-PLS with WarpPLS 3.0 for Nonlinear Relationships in Social and Business Research]", Yogyakarta: ANDI.

Sholihin, M., and R. Pike, 2009. "Fairness in Performance Evaluation and Its Behavioral Consequences." Accounting and Business Research, Vol. 39 (4), 397-413.

Sinclair, A., 1995. "The Chameleon of Accountability: Forms and Discourses." Accounting, Organizations and Society, Vol. 20 (2/3), 219-237

Spekle, R. F., and F. H. M. Verbeeten, 2014. "The Use of Performance Measurement Systems in the Public Sector: Effects on Performance." Management Accounting Research 25, 131-146.

Syachbrani, W., 2014. "Pengaruh FaktorFaktor Teknis and Keorganisasian Terhadap Pengembangan Sistem Pengukuran Kinerja Pemerintah Pusat (Studi Empiris Pada Direktorat Jenderal Anggaran, Kementerian Keuangan Republik 
Indonesia [The Influence of Technical and Organizational Factors on Development of Performance Measurement System of Central Government (Empirical Study On Directorate General of Budget, Ministry of Finance of the Republic of Indonesia]", Unpublished Thesis, Post-Graduate Program. Yogyakarta: UGM.

Talbot, C, 2008. "Performance Regimes - The Institutional Context of Performance Policies." International Journal of Public Administration, 31 (14), 1569-1591.

Verbeeten, F. H. M., 2008. "Performance Management Practices in Public Sector Organizations: Impact on Performance." Accounting, Auditing and Accountability Journal 21, 427-454.

Van de Ven, A. H. and D. L. Ferry, 1980. "Measuring and Assessing Organizations." . New York: Wiley.

Wang, X., 2002. "Assessing Administrative Accountability: Results from A National Survey." American Review of Public Administration, 32 (3), 350-370.
Withey, M., R. L. Daft and W. H. Cooper, 1983. "Measures of Perrow's Work Unit Technology: An Empirical Assessment and A New Scale." Academy of Management Journal 26, 45-63.

Williams, J. J., N. B. Macintosh and J. C. Moore, 1990. "Budget-related Behavior in Public Sector Organization: Some Empirical Evidence." Accounting, Organization and Society 15, 221-246.

Yowi, L. R .K., 2011. "Hubungan FaktorFaktor Implementasi, Pengembangan Sistem, and Hasil Sistem Pengukuran Kinerja (Studi Di Pemerintah Daerah Kabupaten Sumba Timur [The Relationship of Implementation Factors, Systems Development, and Results of Performance Measurement System (Studies In District Government of East Sumba]", Unpublished Thesis, Post-Graduate Program. Yogyakarta: UGM. 